ISSN 1392-3196 / e-ISSN 2335-8947

Zemdirbyste-Agriculture, vol. 107, No. 1 (2020), p. 3-10

DOI 10.13080/z-a.2020.107.001

\title{
Soil respiration and microbial biomass peculiarities as influenced by different land use intensity
}

\author{
Milda MURAŠKIENE $\dot{E}^{1}$, Jūrate ALEINIKOVIENE் $\dot{E}^{2,3}$, Regina SKUODIENË ${ }^{3}$, \\ Donata TOMCHUK ${ }^{3}$, Kęstutis ARMOLAITIS ${ }^{1}$
}

${ }^{1}$ Lithuanian Research Centre for Agriculture and Forestry, Institute of Forestry

Liepų 1, Girionys, Kaunas distr., Lithuania

E-mail: milda.muraskiene@mi.lt

${ }^{2}$ Vytautas Magnus University, Agriculture Academy

Studentų 11, Akademija, Kaunas distr., Lithuania

${ }^{3}$ Lithuanian Research Centre for Agriculture and Forestry, Vėžaičiai Branch

Gargždų 29, Věžaičiai, Klaipèda distr., Lithuania

\begin{abstract}
In agroecosystems, it is important to maintain the soil agroecological potential and its productivity, which depend on soil organic carbon (SOC), biological activity and microbial biomass ensuring soil ecological functions. The aim of this study was to evaluate the soil microbial respiration and biomass in a Bathygleyic Distric Glossic Retisol of different land use intensity. These soil properties were measured in 0-10 and 10-20 cm mineral soil layers of the plough horizon in the biotopes of long-term different use: 1) arable land ( $>70$ years cereal crop rotation), 2 ) temporary grassland (>70 years cereal crop rotation with temporary grassland), 3) perennial grassland (with 15-20 years of semi-natural grassland) and 4) silver birch stand (with 25 years old naturally regenerated forest stand in former agricultural land).

In the study, the most intensive soil respiration was determined in the perennial grassland, silver birch stand and temporary grassland in the moderately acidic $\left(\mathrm{pH}_{\mathrm{KCl}} 5.0\right)$ soil. The concentrations of soil microbial biomass carbon (SMBC) and soil microbial biomass nitrogen (SMBN) were the highest in the silver birch stand, and the lowest concentrations were found in the arable land. In most cases, the activity of soil microorganisms (microbial respiration, SMBC and SMBN) was influenced by SOC, water soluble organic carbon (WSOC), humus and its fraction composition, and soil acidity. Despite this, the study did not show strong correlations between these properties. However, in a long-term perspective of soil use, the conversion of arable land to perennial grasslands or forest plantations can stabilize soil microbial activity due to persistent supply of organic matter.
\end{abstract}

Key words: different biotopes of long-term use, microbial biomass carbon, microbial biomass nitrogen, soil organic carbon, soil respiration rate.

\section{Introduction}

Soils have an inherent quality as related to their physical, chemical and biological properties within the constraints set by climate and ecosystems, the ultimate determinant of soil quality and health is the land manager. It is evident that through the management and naturally occurred changes in biotopes, the apparent impact on soil organic matter (SOM) is depending on soil renaturalisation capacity (Armolaitis et al., 2013). According to Schmidt et al. (2011) and Hoffmann et al. (2012), even small changes in SOM have an impact on ecological balance, global carbon (C) and carbon dioxide $\left(\mathrm{CO}_{2}\right)$ concentration in the atmosphere. Intensive anthropogenic activity leads to soil organic carbon (SOC) depletion and soil degradation, when less organic carbon is released into the soil than decomposed (Kaiser, Kalbitz, 2012).
Even though the differencesin SOMaredetectable between the changing biotopes, the SOM mineralization depends on the biotope and on the abundance and activity of soil microorganisms. Consequently, soil microorganisms perform the mineralization of SOM. In different biotopes soils varied in microbiological processes, abundance and structural composition of microorganisms (Shi, Marschner, 2014). Especially, the differences in plant species composition and abundance influence the soil environment (Kaisermann et al., 2018).

More than $30 \%$ of the total fixed $\mathrm{C}$ is accumulated in mineral soil of grasslands (Acharya et al., 2012). The quantity and quality of root exudate and plant residues depend on the origin of grass cover, which determines the soil nutrient retention (Tomchuk, 2018). Therefore, roots usually maintain soil functional habitats and soil

Please use the following format when citing the article:

Muraškienė M., Aleinikovienė J., Skuodienė R., Tomchuk D., Armolaitis K. 2020. Soil respiration and microbial biomass peculiarities as influenced by different land use intensity. Zemdirbyste-Agriculture, 107 (1): 3-10. DOI 10.13080/z-a.2020.107.001 
microorganism communities. Soil microorganisms also affect plant production, quality and diversity functions. The capture of soil nutrients is completely different in perennial grasslands from that of permanently cultivated soils. Giménez et al. (2016) proved that the differences rely mainly on the management practices and spatial distribution of biogeochemical compartments in soils.

Forest soil properties, including the quantity and quality of SOC stocks, are affected not only by the soil type and climate but also by tree species and forest age. Especially, tree species affects the soil properties (Gundersen, 2014). Due to the differences in forest litter quantity and quality, tree root distribution and depth, the microclimate in soil is varying and corresponds to the SOM (Liaudanskiené, 2009; Shi, Marschner, 2014). Also, the abundance of soil microorganisms is particularly dependent on $\mathrm{C}$ and $\mathrm{N}$ ratio in SOM compartments (Armolaitis et al., 2013). The most commonly used microbial indicators for soil health monitoring are soil microbial biomass carbon (SMBC), soil microbial biomass nitrogen $(\mathrm{SMBN})$ and soil respiration (Růžek et al., 2009). Bowles et al. (2014) stated that SMBC and SMBN concentrations depend on the land use. Nevertheless, the soils in different ecosystems accumulate diverse $\mathrm{C}$ and $\mathrm{N}$ concentrations, the land use controls SOM content through the litter input, decomposition rates and the processes of organic matter stabilization in soils (Liaudanskienè, 2009). Larger stocks of SOC may be accumulated in the forest soils when compared to other land uses (Jones et al., 2009). More often, soil tillage technology (e.g., deep ploughing) has a significant influence on SOM mineralization. Tillage decreases SMBC, SMBN and SOC stocks, because it leads to more intensive mineralization. Therefore, larger amounts of SMBC and SMBN are found in long-term abandoned grasslands or abandoned land compared with continuously managed cropland.

Soil microbial abundance and activity are related to soil physical and chemical properties (Kujur, Patel, 2012). Also, the SMBC and SMBN are affected by the soil acidity. Not only the growing agricultural plants but also microorganisms are influenced by soil liming. According to Fuentes et al. (2006), greater respiration and SMBC were found in limed than in non-limed acidic soils. In the naturally highly acidic soil $\left(\mathrm{pH}_{\mathrm{KCl}} 3.9\right)$, higher $\mathrm{SMBC}$ was determined in the first year of grassland establishment; however, with grassland aging and changing its botanical composition, in the third year, SMBC was significantly greater in the soil with $\mathrm{pH}_{\mathrm{KCl}} 5.0$ (Tomchuk, 2018).
Recently intensified agriculture is orientated towards agroecological potential and increase of current productivity; however, these changes are dependent on soil ecological functions. It is evident that soil ecological functions mainly depend on SOM. In our case study, it is especially important to evaluate the SOM retention of soils with low buffering capacity and sorption, containing high level of toxic $\mathrm{Al}^{3+}$, with intermediate-humus content $(2-3 \%)$ and higher retention of nutrients and water (Repšienè, Karčauskienè, 2016).

We hypothesized that the composition of SOC is closely associated with the activity and biomass of soil microorganisms, when ecosystems are developing under different intensity of land use. The aim of this study was to evaluate the soil microbial respiration and microbial biomass in a Bathygleyic Distric Glossic Retisol of different land use: continuous arable land, temporary grassland, perennial grassland and silver birch stand.

\section{Materials and methods}

Study site. The study was carried out in the experimental site with different biotopes (hereafter - the experimental site) at Véžaičiai Branch of Lithuanian Research Centre for Agriculture and Forestry $\left(55^{\circ} 41^{\prime} \mathrm{N}\right.$, $21^{\circ} 30^{\prime} \mathrm{E}$ ). The experimental site (a total area of $10 \mathrm{ha}$ ) is located on the East Žemaičiai Plateau of a morainic plain (elevation 95-100 $\mathrm{m}$ above sea level). The soil of the experimental site is Bathygleyic Distric Glossic Retisol (WRB, 2014) formed on medium-moraine loam.

From 1940 to 1990, the experimental site was part of the experimental area (more than $70 \mathrm{ha}$ ), where different agricultural practices were investigated and the long-term soil productivity improvement practices in the acidic soils were evaluated. However, since 1990 the old experimental area has been reduced and some part of agricultural area was left abandoned. At the time of this study (2014-2015), the area contained four biotopes of different land use intensity: 1) continuous arable land (AL), more than 70 years with cereal crop rotation, 2)temporary grassland (TG), more than 70 years cereal crop rotation with temporary grassland, 3) perennial grassland (PG), land with 15-20 years of semi-natural grassland, and 4) silver birch stand (SBS), 25 years old naturally regenerated forest stand in former agricultural land. The main chemical and physical characteristics of plough horizons in the studied biotopes are presented in Table 1.

The continuous arable land was more than 70 years under the permanent crop rotation: cereal

Table 1. The main soil chemical and physical characteristics of 0-10 and 10-20 cm soil layers of the plough horizon in the studied biotopes before the establishment of the experimental site

\begin{tabular}{|c|c|c|c|c|c|c|}
\hline Biotope & $\mathrm{pH}_{\mathrm{KCl}}$ & $\begin{array}{l}\text { SOC } \\
\mathrm{g} \mathrm{kg}^{-1}\end{array}$ & $\begin{array}{c}\mathrm{N}_{\text {tot }} \\
\mathrm{g} \mathrm{kg}^{-1}\end{array}$ & $\begin{array}{c}\mathrm{P}_{2} \mathrm{O}_{5} \\
\mathrm{mg} \mathrm{kg}^{-1}\end{array}$ & $\begin{array}{c}\mathrm{K}_{2} \mathrm{O} \\
\mathrm{mg} \mathrm{kg}^{-1}\end{array}$ & $\begin{array}{l}\text { Soil bulk density } \\
\mathrm{g} \mathrm{cm}^{-3}\end{array}$ \\
\hline \multicolumn{7}{|c|}{$0-10 \mathrm{~cm}$} \\
\hline $\mathrm{AL}$ & $4.5 \pm 0.4 \mathrm{bc}$ & $9.5 \pm 0.3 \mathrm{a}$ & $0.9 \pm 0.00 \mathrm{a}$ & $71 \pm 1 \mathrm{~b}$ & $194 \pm 6 \mathrm{ab}$ & $1.43 \pm 0.28 \mathrm{a}$ \\
\hline TGA & $3.9 \pm 0.1 \mathrm{a}$ & $13.8 \pm 1.1 \mathrm{~b}$ & $1.3 \pm 0.00 \mathrm{c}$ & $163 \pm 10 \mathrm{e}$ & $201 \pm 6 b$ & $1.36 \pm 0.04 \mathrm{a}$ \\
\hline TGSA & $5.0 \pm 0.2 \mathrm{c}$ & $13.4 \pm 0.7 b$ & $1.3 \pm 0.00 \mathrm{c}$ & $135 \pm 7 \mathrm{~d}$ & $196 \pm 7 \mathrm{ab}$ & $1.37 \pm 0.03 \mathrm{a}$ \\
\hline PG & $5.0 \pm 0.2 \mathrm{c}$ & $13.9 \pm 1.0 \mathrm{~b}$ & $1.0 \pm 0.00 \mathrm{~b}$ & $51 \pm 8 \mathrm{a}$ & $185 \pm 8 \mathrm{a}$ & $1.46 \pm 0.30 \mathrm{a}$ \\
\hline SBS & $4.5 \pm 0.2 b$ & $12.6 \pm 0.6 \mathrm{~b}$ & $0.9 \pm 0.01 \mathrm{a}$ & $86 \pm 6 c$ & $307 \pm 26 \mathrm{c}$ & $1.46 \pm 0.45 \mathrm{a}$ \\
\hline \multicolumn{7}{|c|}{$10-20 \mathrm{~cm}$} \\
\hline $\mathrm{AL}$ & $4.5 \pm 0.4 b c$ & $10.1 \pm 0.3 \mathrm{a}$ & $0.9 \pm 0.00 \mathrm{~b}$ & $77 \pm 6 \mathrm{c}$ & $207 \pm 10 b$ & $1.61 \pm 0.29 \mathrm{ab}$ \\
\hline TGA & $3.9 \pm 0.1 \mathrm{a}$ & $14.1 \pm 1.2 \mathrm{~b}$ & $1.3 \pm 0.00 \mathrm{~d}$ & $162 \pm 9 \mathrm{e}$ & $200 \pm 4 b$ & $1.33 \pm 0.05 \mathrm{a}$ \\
\hline TGSA & $5.0 \pm 0.3 \mathrm{c}$ & $12.1 \pm 0.8 \mathrm{~b}$ & $1.4 \pm 0.00 \mathrm{e}$ & $135 \pm 7 \mathrm{~d}$ & $192 \pm 6 b$ & $1.38 \pm 0.05 \mathrm{ab}$ \\
\hline PG & $5.0 \pm 0.2 \mathrm{c}$ & $11.9 \pm 1.3 \mathrm{~b}$ & $1.0 \pm 0.01 \mathrm{c}$ & $51 \pm 9 \mathrm{a}$ & $107 \pm 2 \mathrm{a}$ & $1.56 \pm 0.24 \mathrm{ab}$ \\
\hline SBS & $4.2 \pm 0.1 \mathrm{~b}$ & $9.0 \pm 1.1 \mathrm{a}$ & $0.8 \pm 0.01 \mathrm{a}$ & $63 \pm 6 \mathrm{~b}$ & $197 \pm 8 \mathrm{~b}$ & $1.59 \pm 0.12 \mathrm{~b}$ \\
\hline
\end{tabular}

Note. AL - arable land, TGA - temporary grassland (TG) in acidic soil, TGSA - TG in slightly acidic soil, PG - perennial grassland, SBS - silver birch stand; SOC - soil organic carbon, $\mathrm{N}_{\text {tot }}$ - total nitrogen; values are the mean of 5 samples and respective standard deviations; values in the same row of plough horizon followed by a different letter indicate significant $(p<0.05)$ differences between the means. 
crop rotation prevailed, mainly with common oat (Avena sativa L.), narrow-leaved lupine (Lupinus angustifolius L.), winter rye (Secale cereale L.) and buckwheat (Fagopyrum esculentum Moench). In the autumn 2014, the winter rye 'Duoniai' was sown after the green manure of narrow-leaved lupine 'Derliai'. In general, deep ploughing $(20-25 \mathrm{~cm})$ was conducted in arable land every year, and mineral nitrogen $\left(\mathrm{N}_{\min }\right)$ for supplementary plant nutrition was applied, source of $\mathrm{N}$ - urea $(46 \% \mathrm{~N})$ up to $100 \mathrm{~kg} \mathrm{ha}^{-1} \mathrm{~N}$ per growing season.

As for the temporary grassland, in 2015 two experimental locations were selected: one temporary grassland in naturally acidic soil (TGA) (soil $\mathrm{pH}_{\mathrm{KC}}$ in the studied location varied in the range from 3.8 to 4.0 ) and the other - temporary grassland in slightly acidic soil (TGSA) (soil $\mathrm{pH}_{\mathrm{KCl}}$ in the studied location varied in the range from 4.7 to 5.3 ). To increase the acidity, before the establishment of temporary grasslands, naturally acidic soils were limed once applying dolomite at $7 \mathrm{t} \mathrm{ha}^{-1}$ $\mathrm{CaCO}_{3}$ (calcium carbonate) rate in the autumn in the part of continuous arable land. The main cereal crop spring barley (Hordeum vulgare L.) 'Luokè' was sown after two different legume-grass swards: (1) white clover (Trifolium repens L.) 'Nemuniai' and (2) hybrid clover (Trifolium hybridum L.) 'Lomiai' (both $50 \%$ in composition), mixed with timothy-grass (Phleum pratense L.) 'Dubingiai' $(35 \%)$ and meadow grass (Poa pratensis L.) 'Rusne' $(15 \%)$. TGA and TGSA, established with both legumegrass compositions, represented the following temporary grassland biotopes: 1) temporary grassland in acidic soil with white clover and grasses (TGA1);2) temporary grassland in acidic soil with hybrid clover and grasses (TGA2); 3) temporary grassland in slightly acidic soil with white clover and grasses (TGSA1); 4) temporary grassland in slightly acidic soil with hybrid clover and grasses (TGSA2).

The perennial grassland biotope was selected in 2015. It originated from the abandoned former temporary grassland sown about 15-20 years ago. In abandoned old grassland, the conversion to the semi-natural grassland was observed with predominant Poaceae, Asteraceae, Polygonaceae and Fabaceae and in less extent with some other plant families. Even though the meadow in the perennial grassland biotope is naturally regenerated, an insignificant human maintenance of grasslands is continuously carried out (cutting once per vegetation). However, during the intensive vegetation, the abandoned grassland appears to be in the mosaic variation of plant phytocenosis with ecological niches for more adapted to soil conditions plant species and with some tracheophytes: Pilosella caespitosa aggr., Ranunculus repens L., Vicia tetrasperma (L.) Schreb., Trifolium dubium Faden-Klee), Trifolium aureum Pollich, Phalacroloma annuum L. Dumort., Taraxacum officinale L. and Lathyrus pratensis L.

In 2015, in the abandoned agricultural area the naturally regenerated silver birch (Betula pendula Roth) stands were 25-year-old with the mixture of 10-year-old Norway spruce (Picea abies (L.) Karst.) in the undergrowth. In the stands, the first thinning was performed in 2010, and in 2015 the birch tree density had reached in average of 590 birch tree stems ha ${ }^{-1}$ with stem volume of $93 \mathrm{~m}^{3} \mathrm{ha}^{-1}$.

Soil sampling, chemical and microbiological estimations. All the studied biotopes are established in former agricultural land with a well-expressed plough (Ap) horizon. The identification of the plough horizon was performed by visual examination of mineral soil profile (up to $1 \mathrm{~m}$ in depth). The plough horizon layers $(0-10$ and $10-20 \mathrm{~cm})$ were distinguished and soil bulk density was determined (Table 1). For the estimation of mineral soil chemical and microbiological properties, at the end of vegetation, the composite soil samples (each sampling was done at 5 systematically selected points) were collected from plough horizon layers $(0-10$ and $10-20 \mathrm{~cm})$ in 2015.

Soil bulk density was determined by ISO 11272 (ISO 11272:1998. Soil quality - Determination of dry bulk density. Physical properties of soils). Soil acidity $\left(\mathrm{pH}_{\mathrm{KCI}}\right)$ was determined potentiometrically in $1 \mathrm{M} \mathrm{KCl}$ suspension (ISO 10390:2005. Soil quality Determination of $\mathrm{pH}$ ); concentrations of total soil organic carbon (SOC) - by dry combustion at $900^{\circ} \mathrm{C}$ with TOC analyser (Elementar Analysensysteme $\mathrm{GmbH}$, Germany (ISO 10694:1995. Soil quality - Determination of organic and total carbon after dry combustion), total nitrogen $\left(\mathrm{N}_{\text {to }}\right)$ - by the Kjeldhal method (ISO 11261:1995. Soil quality - Determination of total nitrogen - Modified Kjeldahl method); mobile potassium $\left(\mathrm{K}_{2} \mathrm{O}\right)$ and mobile phosphorus $\left(\mathrm{P}_{2} \mathrm{O}_{5}\right)$ were determined by the Egner-RiehmDomingo (A-L) method (Egnér et al., 1960). Hot water extractable organic carbon (WEOC), which is used as a measure for potentially bioavailable soil organic matter (SOM), was determined according to Schulz et al. (2004). Humus was determined according to the Tyurin method modified by Nikitin (1999). Faithfull (2002) method was used for determination of humus fraction composition (fulvic and humic acids).

For the evaluation of soil microbial activity in the plough horizon, soil microbial respiration rate (SMRR), soil microbial biomass carbon (SMBC) and soil microbial biomass nitrogen (SMBN) were determined. The SMRR as $\mathrm{CO}_{2}$ emission of the soil was measured by the titration method, where the emitted $\mathrm{CO}_{2}$ was absorbed by $\mathrm{NaOH}$ solution (Shinner et al., 1993). SMBC and SMBN were measured by the fumigation-extraction method (Vance et al., 1987). Soil samples were fumigated by exposing soil to alcohol-free chloroform $\left(\mathrm{CHCl}_{3}\right)$ vapour for $24 \mathrm{~h}$ in a vacuum desiccator (SS-ISO 14240-2:2011. Soil quality - Determination of soil microbial biomass. Fumigation extraction method)

The concentration of SMBC $\left(\mu \mathrm{g} \mathrm{g}^{-1} \mathrm{C}\right.$ soil dry matter (DM)) was calculated according to Vance et al. (1987) taking the $0.5 \mathrm{M} \mathrm{K}_{2} \mathrm{SO}_{\text {extract efficiency factor }}$ 0.38 . The concentration of SMBN $\left(\mu \mathrm{g} \mathrm{g}^{-1} \mathrm{~N}\right.$ soil DM) was calculated according to Brookes et al. (1985) taking the $\mathrm{K}_{2} \mathrm{SO}_{4}$ extract efficiency factor 0.54 .

Agrometeorological conditions. Western region of Lithuania is strongly affected by the maritime climate; in comparison with the country's eastern region, it is warmer in winter and cooler in summer. During the last 40 years, the locality has been receiving the highest rate of precipitation, which has amounted to an average of $934 \mathrm{~mm}$ annually and $554 \mathrm{~mm}$ during the growing season. The average annual temperature is $7.0^{\circ} \mathrm{C}$, with an average maximum of $17.3^{\circ} \mathrm{C}$ in July and with an average minimum of $-2.4^{\circ} \mathrm{C}$ in January. In 2014, during intense growing season in May and June, the weather was dry and cool; especially it was dry in the month of July, when the rainfall amounted to as little as $33.8 \mathrm{~mm}$, or $38 \%$ of the standard climate norm (SCN). Dry period lasted until the middle of August. In the growing season of 2015, the rainfall accounted for $83 \%$ of SCN. Especially it was dry in August (rainfall amounted to $12.5 \mathrm{~mm}$, or $13 \%$ of SCN) and in October (13.6 mm, or $14 \%$ of SCN).

Statistical analysis. The data were statistically processed using the analysis of variance (ANOVA). The significant differences between the means were established by the least significant difference at a significance level of $p \leq 0.05$ (Raudonius, 2017). 


\section{Results and discussion}

Soil organic carbon (SOC) content and humus composition. Even though the soil in the experimental site had been cultivated intensively in the past, over the last 25 years SOC content did not change essentially in all studied biotopes (Table 1). As it was indicated by Plesevičienè (1993), in 1990 the SOC in the former longterm soil productivity experiment was sustained on the average of $11.9 \mathrm{~g} \mathrm{~kg}^{-1} \mathrm{C}$, while in $2015-12.0 \mathrm{~g} \mathrm{~kg}^{-1} \mathrm{C}$.

In the plough layers of different biotopes the mean content of SOC varied from 9.0 to $14.1 \mathrm{~g} \mathrm{~kg}^{-1}$ (Table 1). In the soil of the continuous agricultural maintenance (cropland), in the surface layer (up to 10 $\mathrm{cm}$ ), the content of SOC was 1.5 times lower compared to the other biotopes. However, in the deeper layer $(10-20 \mathrm{~cm}) \mathrm{SOC}$ was lower in the arable land and silver birch stand. Therefore, the results indicated that in the potentially slightly acidic soil the organic matter is not lacking in the studied biotopes. It is important to state that under the established and consistent plant cover the ecosystem regulates the stabilization even of C stocks in the soil (Kaisermann et al., 2018).
It is evident from our case study that in the biotopes the humus content increased along with increase in SOC content. Higher humus content was determined in temporary grassland, especially in the slightly acidic soil with overgrown hybrid and white clover (Table 2). The lowest humus content was identified in the arable land in $0-10 \mathrm{~cm}(1.64 \%$ to $1.79 \%)$ and in the silver birch stand in $0-10 \mathrm{~cm}(1.56 \%)$. However, the data by Plesevičiene (1993) indicate that acidic $\left(\mathrm{pH}_{\mathrm{KCl}} 4.1-4.3\right)$ soils have the potential of humus accumulation. The content of humus varied insignificantly from $1.90-2.16 \%$ to $1.52-2.46 \%$, respectively, in naturally acidic and in slightly acidic soils. It has been documented that SOC could buffer the soil $\mathrm{pH}$ changes (Skuodienè et al., 2017).

Organic matter humification influences the biological stabilization of soil organic carbohydrates. For that, more diverse humus substances could be located in the humus fraction composition (Li et al., 2017). However, in our study, the humus in plough horizon in the biotopes of different use mainly contained non-extractable residues (Table 2). The non-extractable residues exceeded $99 \%$ and varied in a narrow interval between the biotopes. The results are relevant to other investigations, indicating that

Table 2. Soil humus, humus fraction composition and water extractable organic carbon (WEOC) content in the studied biotopes of different use

\begin{tabular}{|c|c|c|c|c|c|}
\hline \multirow[b]{2}{*}{ Biotope } & \multirow{2}{*}{$\begin{array}{l}\text { Humus } \\
\quad \%\end{array}$} & \multicolumn{3}{|c|}{ Humus fraction composition $\%$} & \multirow{2}{*}{$\begin{array}{c}\text { WEOC } \\
\mathrm{g} \mathrm{kg}^{-1}\end{array}$} \\
\hline & & $\begin{array}{c}\text { non-extractable } \\
\text { residues }\end{array}$ & $\begin{array}{c}\text { humic } \\
\text { acids }\end{array}$ & $\begin{array}{l}\text { fulvic } \\
\text { acids }\end{array}$ & \\
\hline \multicolumn{6}{|c|}{$0-10 \mathrm{~cm}$} \\
\hline $\mathrm{AL}$ & $1.64 \pm 0.05 \mathrm{a}$ & $99.74 \pm 0.03 b$ & $0.19 \pm 0.03 \mathrm{a}$ & $0.07 \pm 0.00 \mathrm{a}$ & $0.423 \pm 0.04 \mathrm{a}$ \\
\hline TGA1 & $2.04 \pm 0.18 b$ & $99.59 \pm 0.06 \mathrm{a}$ & $0.27 \pm 0.04 \mathrm{~b}$ & $0.14 \pm 0.01 \mathrm{bc}$ & $0.749 \pm 0.05 \mathrm{c}$ \\
\hline TGA2 & $2.20 \pm 0.33 \mathrm{bc}$ & $99.52 \pm 0.06 \mathrm{a}$ & $0.33 \pm 0.06 b c$ & $0.15 \pm 0.00 \mathrm{c}$ & $0.798 \pm 0.05 \mathrm{~cd}$ \\
\hline TGSA1 & $2.71 \pm 0.22 \mathrm{c}$ & $99.55 \pm 0.03 \mathrm{a}$ & $0.37 \pm 0.01 \mathrm{c}$ & $0.09 \pm 0.01 \mathrm{a}$ & $0.893 \pm 0.07 \mathrm{~d}$ \\
\hline TGSA2 & $2.67 \pm 0.10 \mathrm{c}$ & $99.58 \pm 0.03 \mathrm{a}$ & $0.34 \pm 0.03 \mathrm{bc}$ & $0.08 \pm 0.01 \mathrm{a}$ & $0.844 \pm 0.07 \mathrm{~cd}$ \\
\hline PG & $2.40 \pm 0.17 \mathrm{c}$ & $99.58 \pm 0.01 \mathrm{a}$ & $0.32 \pm 0.01 \mathrm{~b}$ & $0.11 \pm 0.02 \mathrm{ab}$ & $0.657 \pm 0.04 \mathrm{~b}$ \\
\hline SBS & $2.19 \pm 0.10 b c$ & $99.52 \pm 0.07 \mathrm{a}$ & $0.35 \pm 0.07 b c$ & $0.13 \pm 0.01 \mathrm{~b}$ & $0.627 \pm 0.02 b$ \\
\hline \multicolumn{6}{|c|}{$10-20 \mathrm{~cm}$} \\
\hline $\mathrm{AL}$ & $1.79 \pm 0.07 \mathrm{ab}$ & $99.72 \pm 0.03 \mathrm{c}$ & $0.22 \pm 0.02 \mathrm{a}$ & $0.07 \pm 0.00 \mathrm{a}$ & $0.440 \pm 0.04 \mathrm{a}$ \\
\hline TGA1 & $1.88 \pm 0.06 \mathrm{~b}$ & $99.58 \pm 0.02 \mathrm{~b}$ & $0.29 \pm 0.01 \mathrm{~b}$ & $0.14 \pm 0.01 \mathrm{c}$ & $0.737 \pm 0.08 \mathrm{c}$ \\
\hline TGA2 & $2.12 \pm 0.37 b c$ & $99.53 \pm 0.06 \mathrm{ab}$ & $0.31 \pm 0.04 b$ & $0.16 \pm 0.03 \mathrm{c}$ & $0.834 \pm 0.09 \mathrm{c}$ \\
\hline TGSA1 & $2.75 \pm 0.15 c$ & $99.51 \pm 0.01 \mathrm{a}$ & $0.39 \pm 0.01 \mathrm{c}$ & $0.10 \pm 0.01 \mathrm{~b}$ & $0.759 \pm 0.05 \mathrm{c}$ \\
\hline TGSA2 & $2.56 \pm 0.11 \mathrm{c}$ & $99.45 \pm 0.08 \mathrm{a}$ & $0.45 \pm 0.08 \mathrm{c}$ & $0.10 \pm 0.01 \mathrm{~b}$ & $0.753 \pm 0.01 \mathrm{c}$ \\
\hline PG & $2.05 \pm 0.33 \mathrm{ab}$ & $99.61 \pm 0.04 b$ & $0.29 \pm 0.03 \mathrm{~b}$ & $0.10 \pm 0.01 \mathrm{~b}$ & $0.587 \pm 0.00 \mathrm{~b}$ \\
\hline SBS & $1.56 \pm 0.19 \mathrm{a}$ & $99.62 \pm 0.03 b$ & $0.29 \pm 0.02 b$ & $0.10 \pm 0.00 \mathrm{~b}$ & $0.463 \pm 0.02 \mathrm{a}$ \\
\hline
\end{tabular}

Note. AL - arable land, TGA1 - temporary grassland (TG) in acidic soil with white clover and grasses, TGA2 - TG in acidic soil with hybrid clover and grasses, TGSA1 - TG in slightly acidic soil with white clover and grasses, TGSA2 - TG in slightly acidic soil with hybrid clover and grasses, PG - perennial grassland, SBS - silver birch stand; values are the mean of 5 samples and respective standard deviations; values in the same row of plough horizon $0-10$ and $10-20 \mathrm{~cm}$ depth followed by a different letter indicate significant $(p<0.05)$ differences between the means.

non-extractable fractions impact on the humus stability and further are assimilating in microbial constitutions or even in soil aggregates (Armolaitis et al., 2013). Our results also indicated a higher dominance of humic acids instead of fulvic acids (Table 2). It is evident that the content of humic acids was about 1.5-times higher in the temporary grassland in slightly acidic soil with overgrown white clover $(0.37-0.39 \%)$ and hybrid clover $(0.34-0.45 \%)$ than in the arable land $(0.19-0.22 \%)$. As well as in perennial grassland and silver birch stand the content of humic acids increased.

In contrast, the content of fulvic acids was significantly higher $(p<0.05)$ in the temporary grassland in acidic soil $\left(\mathrm{pH}_{\mathrm{KCl}} 3.9\right)$ with white clover as well as in perennial grassland and silver birch stand (Table 2). Humic acids are biologically important contributors to microbial activity. Water extractable organic carbon (WEOC) is the most mobile soil $\mathrm{C}$ source, mainly regulated by soil temperature and moisture, and serves as a potential nutrient source to soil microorganisms and plants (Bowles et al., 2014). Fulvic acids, in comparison to humic acids, contribute directly to efficient nutrient uptake and utilization from soils (Garcia, Kao-Kniffin, 2018). It is evident that solubility of phosphorus was $2-3$ times higher in the temporary grassland in the acidic soil and was increasing along the increase of fulvic acids (Table 2).

WEOC in the soil depends on the agricultural management and crop rotation (Liaudanskienè, 2009). According to Duffková and Makurová (2011), the higher concentration of WEOC, the more nutrients are available for plants and soil microorganisms. In our study, the content of WEOC ranged from 0.423 to $0.893 \mathrm{~g} \mathrm{~kg}^{-1}$ and was significantly lowest in the continuous arable land (Table 2). Meanwhile, the highest content of WEOC was estimated in the plough horizon (up to $10 \mathrm{~cm}$ depth) in temporary grassland in slightly acidic soil (ranged from 0.844 to $0.893 \mathrm{~g} \mathrm{~kg}^{-1}$ ) and with lower extent in temporary grassland in acidic soil (ranged from 0.749 to 
$\left.0.798 \mathrm{~g} \mathrm{~kg}^{-1}\right)$. In the deeper layers of the plough horizon the content of WEOC tended to be lower in all the studied biotopes, except for the temporary grassland, where it was higher. Similar trends in WEOC among different biotopes were determined by Armolaitis et al. (2013). Thus, it was indicated that WEOC content in the soil could depend on liming and fertilization. Liaudanskiene (2009) suggests that incorporated plant residues may increase the WEOC too.

However, it was estimated that over the last 25 years humus content was not decreasing along the different land use with the exception of continuous arable land (the data on the organic matter humification intensity are not shown). Skuodienè et al. (2017) have indicated that the $\mathrm{C}: \mathrm{N}$ in the plough horizons significantly differed $(p<0.05)$ between the biotopes. Consequently, in the perennial grassland and silver birch stand, the C:N was much higher than in the arable land. However, the data were significantly different when comparing $\mathrm{C}: \mathrm{N}$ in temporary grassland. There, the $\mathrm{C}: \mathrm{N}$ was on average 12 and decreased to 9 , in the plough horizon of $0-10$ and $10-20 \mathrm{~cm}$ depth, respectively. It is noteworthy that $\mathrm{C}: \mathrm{N}$ in the temporary grassland could have a wider variation due to different $\mathrm{pH}$ value. Consequently, $\mathrm{C}: \mathrm{N}$ was the highest, when the temporary grasslands were settled in acidic soil. These results were unexpected, since they show the exact opposite of the humus increasing trends along the temporary grassland establishment in the continuously used arable land (Giménez et al., 2016). The C:N is indicative of the quality of the humified organic matter in the soil (Jones et al., 2009) and of the intensity of organic matter decomposition. It is common that the optimal C:N in the soil is around 10. The decreasing C:N correlated with high humification degree, while the increasing $\mathrm{C}: \mathrm{N}$ correlated with nutrient immobilization.

Soil microbial respiration rate (SMRR) also provides direct indication of organic matter mineralization rate and heterotrophic metabolism activity in soils (Eisenhauer et al., 2017). In our study, SMRR $\left(\mathrm{CO}_{2}\right.$ emission per day) in the plough horizon (up to $20 \mathrm{~cm}$ depth) ranged from 0.022 to $0.049 \mathrm{mg} \mathrm{g}^{-1} \mathrm{CO}_{2} \mathrm{DM}$ (Fig. 1) and was the highest in perennial grassland and the lowest in arable land. In temporary grassland, SMRR was 3-4 times higher at up to $10 \mathrm{~cm}$ depth than at $10-20 \mathrm{~cm}$ depth. However, there were only the tendencies $(p>0.05)$ that higher SMRR could be induced along with higher soil $\mathrm{pH}$ values. The influence of the heterogeneity of soil acidity on soil SMRR was confirmed by other research studies (Bowles et al., 2014).

Microbial biomass in the soil is a functional response of microorganisms to decomposition, SOM turnover and nutrient transformation (Eisenhauer et al., 2017). The content of SMBC and SMBN could reflect the microbial activity. The SMBC ranged from 125.6 to $504.9 \mu \mathrm{g} \mathrm{g}^{-1} \mathrm{C}$ DW between the studied biotopes (Fig. 2).

The lowest SMBC content was in slightly acidic soil in the arable land (125.6-138.1 $\left.\mu \mathrm{g} \mathrm{g}^{-1} \mathrm{C} \mathrm{DW}\right)$ and temporary grassland (191.9-215.5 $\mathrm{gg} \mathrm{g}^{-1} \mathrm{C} \mathrm{DW}$ ) and the highest contents were in the silver birch stand (472.2-504.9 $\left.\mathrm{g} \mathrm{g}^{-1} \mathrm{C} \mathrm{DW}\right)$. It should be noted that

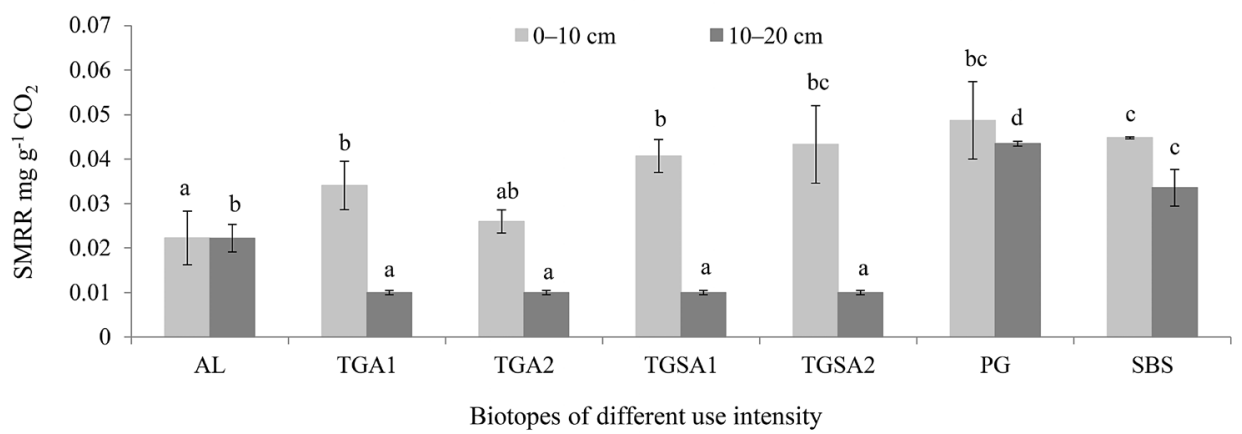

Note. AL - arable land, TGA1 - temporary grassland (TG) in acidic soil with white clover and grasses, TGA2 - TG in acidic soil with hybrid clover and grasses, TGSA1 - TG in slightly acidic soil with white clover and grasses, TGSA2 - TG in slightly acidic soil with hybrid clover and grasses, PG - perennial grassland, SBS - silver birch stand; bars denote standard error; different letters above the columns indicate statistically significant differences between different biotopes $(p<0.05)$.

Figure 1. The mean soil microbial respiration rate (SMRR) in 0-10 and 10-20 cm soil layers of plough horizon in the different land use intensity

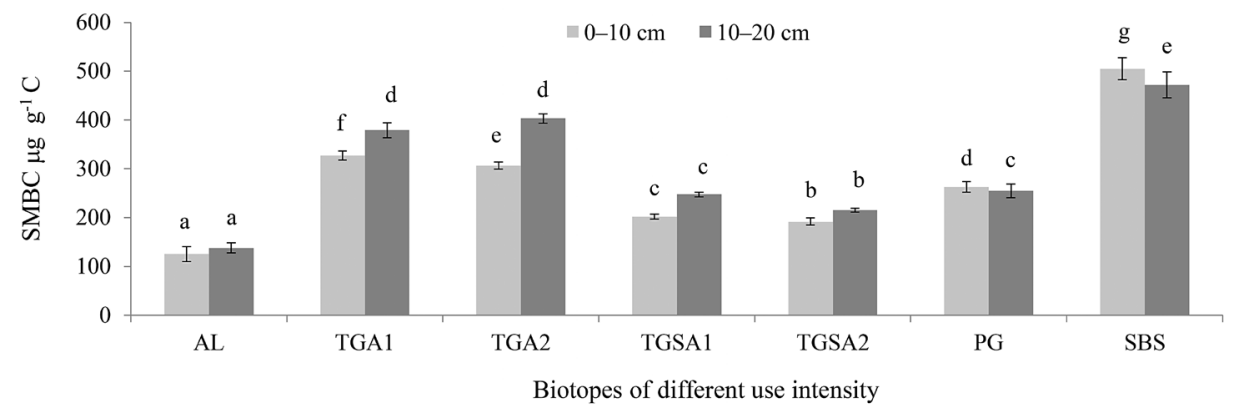

Explanations under Figure 1

Figure 2. The mean concentrations of soil microbial biomass carbon (SMBC) in 0-10 and 10-20 cm soil layers of plough horizon in the different land use intensity 
SMBC concentrations were slightly higher in $10-20 \mathrm{~cm}$ layer of the studied plough horizons only in the temporary grassland. The higher SMBC in grassland and in silver birch stand compared to arable land relates to differences in SOM as well as in SOC quality between the biotopes. Various SOC sources determine the increase potential for microbial decomposition activities (ZechmeisterBoltenstern et al., 2015). In different biotopes, SMBC content was $190 \mu \mathrm{g} \mathrm{g}^{-1} \mathrm{C} \mathrm{DW}$ in the arable land, 280 $\mu \mathrm{g} \mathrm{g}^{-1} \mathrm{C} \mathrm{DW}-$ in the grassland and $450 \mu \mathrm{g} \mathrm{g}^{-1} \mathrm{C} \mathrm{DW}$ - in the forest ecosystem (Aleinikovienè et al., 2017). According to Anderson and Domsch (2010), the main factor influencing SMBC concentrations is the land use intensity. Shi and Marschner (2014) have reported that in forested land $\mathrm{MBC}$ is higher than in grasslands or arable land. In addition, SMBC in grasslands depends on grassland cultivation duration.
SMBN varied from 12.3 to $42.0 \mu \mathrm{g} \mathrm{g}^{-1} \mathrm{~N} \mathrm{DW}$, and it was clearly expressed that significantly lowest $(p<0.05)$ SMBN concentration was in the plough horizon of continuous arable land (Fig. 3). However, when compared to the arable land, SMBN concentration in perennial grassland was almost twice as high. The SMBN concentration in the plough horizon of the silver birch stand was 1.7-3.4 times higher compared to that in other biotopes. In temporary grassland, SMBN concentration corresponded to the soil $\mathrm{pH}$ value. This could indicate intensification of SOM mineralization or intense changes in microbial activity in the biotopes.

In this study, the estimated SMBN content values were similar or slightly lower than those reported by other researchers. Kujur and Patel (2012) have documented that $\mathrm{SMBN}$ concentrations in agricultural lands can range from 4.8 to $67.9 \mu \mathrm{g} \mathrm{g}^{-1} \mathrm{~N}$ DW. In grassland, SMBN may

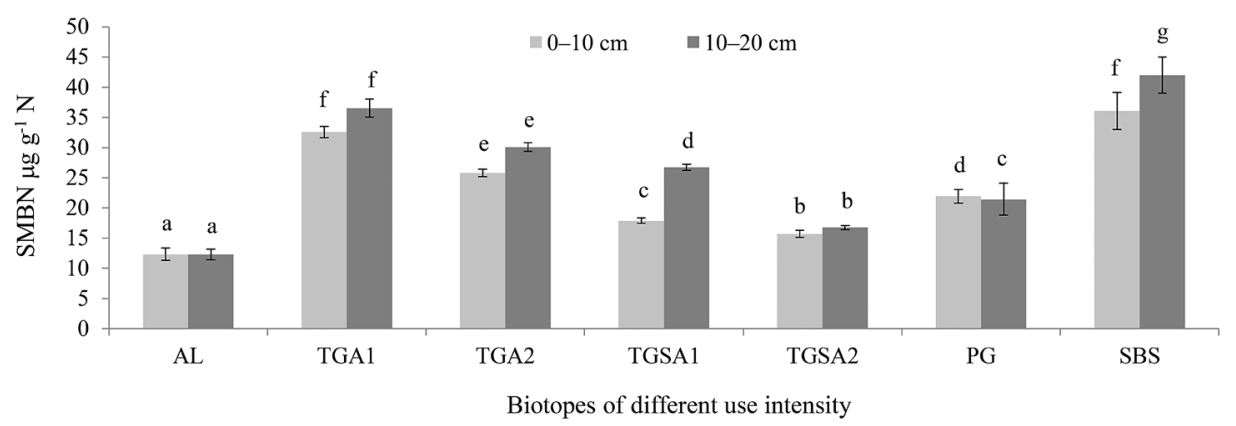

Explanations under Figure 1

Figure 3. The mean concentrations of soil microbial biomass nitrogen (SMBN) in 0-10 and 10-20 cm soil layers of the plough horizon in the different land use intensity

increase to $100 \mu \mathrm{g} \mathrm{g}^{-1} \mathrm{~N}$ DW or to be even higher in forest soils - $130 \mu \mathrm{g} \mathrm{g}^{-1} \mathrm{~N}$ DW. The increase in SMBC and SMBN is mainly correlated with the increase in SOM and nutrients. The decrease in SMBC and SMBN reflects the decreasing content of organic residues either in the SOM as a result of the decreasing $\mathrm{C}$ input rate of plant roots (Armolaitis et al., 2013). Microorganisms require balancing of nutrients in the soil for the take-over of $\mathrm{C}$ and $\mathrm{N}$ to increase in biomass and extract the energy for the activity (Anderson, Domsch, 2010; Shi, Marschner, 2014; Skuodienè et al., 2017).

In the present study it was noted that changes in the soil microbial activity are related to the different land use intensity. In more naturally developing grassland and forest land with lower soil management intensity, microbial biomass increases during humification. However, in continuous arable land the potentially active microbial biomass was associated with the SOC content.

\section{Conclusions}

1. Under humid climate conditions of Western Lithuania, the microbial biomass and soil respiration depended on the biotope of different land use. The highest contents of soil microbial biomass carbon and nitrogen (SMBC and SMBN) were found in the silver birch stand and temporary grassland, and the lowest contents were found in the continuous arable land.

2. The highest soil microbial respiration rate (SMRR) was found in the perennial grassland and silver birch stand. In the temporary grassland, SMRR showed higher variation in the plough horizon: it was 3-4 times higher in the $10 \mathrm{~cm}$ topsoil than at $10-20 \mathrm{~cm}$ depth. The higher SMRR could also be related to the higher soil $\mathrm{pH}$ value.

3. The highest humus content was found in the temporary grassland with moderate acidic soil and in the perennial grassland. Irrespective of the soil acidity $(\mathrm{pH})$, the highest water extractable organic carbon (WEOC) content was found in the temporary grassland. In the long-term perspective, the different management of arable land, especially establishment of perennial grasslands and birch stands, can stabilize the microbial activity through the progressive supply and turnover of organic matter.

\section{Acknowledgements}

The paper presents research findings, obtained through the long-term research programme "Sustainable Forestry and Global Changes" and programme "Productivity and Sustainability of Agricultural and Forest Soils" implemented by Lithuanian Research Centre for Agriculture and Forestry. Also the chapter presents research findings, obtained through the project "The Effect of Long-Term Management of Resources of Varying Intensity on the Soils of Different Genesis and Other Components of Agro-Ecosystems" (SIT-9/2015) funded by the Research Council of Lithuania.

Received 11062019 Accepted 19112019 


\section{References}

1. Acharya B. S., Rasmussen J., Eriksen J. 2012. Grassland carbon sequestration and emissions following cultivation in a mixed crop rotation. Agriculture, Ecosystems and Environment, 153: 33-39.

https://doi.org/10.1016/j.agee.2012.03.001

2. Aleinikovienė J., Armolaitis K., Česnulevičienė R., Žèkaitè V., Muraškienè M. 2017. The status of soil organic matter decomposing microbiota in afforested and abandoned arable Arenosols. Zemdirbyste-Agriculture, 104 (3): 195-202.

https://doi.org/10.13080/z-a.2017.104.025

3. Anderson T. H., Domsch K. H. 2010. Soil microbial biomass: the eco-physiological approach. Soil Biology and Biochemistry, 42: 2039-2043.

https://doi.org/10.1016/j.soilbio.2010.06.026

4. Armolaitis K., Aleinikoviené J., Lubytė J., Žèkaitė V., Garbaravičius P. 2013. Stability of soil organic carbon in agro and forest ecosystems on Arenosols. ZemdirbysteAgriculture, 100 (3): 227-234.

https://doi.org/10.13080/z-a.2013.100.029

5. Bowles T. M., Acosta-Martínez V., Calderón F., Jackson L. E. 2014. Soil enzyme activities, microbial communities, and carbon and nitrogen availability in organic agroecosystems across an intensively-managed agricultural landscape. Soil Biology and Biochemistry, 68: 252-262.

https://doi.org/10.1016/j.soilbio.2013.10.004

6. Brookes P. C., Landman A., Pruden G., Jenkinson D. S. 1985. Chloroform fumigation and release of soil nitrogen: a rapid extraction method to measure microbial biomass nitrogen in soil. Soil Biology and Biochemistry, 17: 837-842.

https://doi.org/10.1016/j.soilbio.2013.10.004

7. Duffková R., Macurová H. 2011. Soil biological quantity and quality parameters of grasslands in various landscape zones. Plant, Soil and Environment, 57: 577-582. https://doi.org/10.17221/475/2011-PSE

8. Egnér H., Riehm H., Domingo W. R. 1960. Untersuchungenüber die chemische Bodenanalyse als Grundlage für die Beurteilung des Nährstoffzustandes der Böden. II. Chemische Extraktionsmethoden zur Phosphor - und Kaliumbestimmung. Kungliga Lantbrukshögskolans Annaler, 26: 199-215 (in German).

9. Eisenhauer N., Lanoue A., Strecker T., Scheu S., Steinauer K., Thakur M. P., Mommer L. 2017. Root biomass and exudates link plant diversity with soil bacterial and fungal biomass. Scientific Reports, 7: 44641. https://doi.org/10.1038/srep44641

10. Faithfull N. T. 2002. Methods of agricultural chemical analysis: a practical handbook. University of Wales, $\mathrm{UK}, 304 \mathrm{p}$. https://doi.org/10.1079/9780851996080.0000

11. Fuentes J. P., Bezdicek D. F., Flury M., Albrecht S., Smith J. L. 2006. Microbial activity affected by lime in a long-term no-till soil. Soil and Tillage Research, 88: 123-131. https://doi.org/10.1016/j.still.2005.05.001

12. Garcia J., Kao-Kniffin J. 2018. Microbial group dynamics in plant rhizospheres and their implications on nutrient cycling. Frontiers in Microbiology, 9: 1516. https://doi.org/10.3389/fmicb.2018.01516

13. Giménez M. G., Della Peruta R., de Jong R., Keller A., Schaepman M. E. 2016. Spatial differentiation of arable land and permanent grassland to improve a land management model for nutrient balancing. IEEE Journal of Selected Topics in Applied Earth Observations and Remote Sensing, 9 (12): 5655-5665. https://doi.org/10.1080/09064710.2017.1293724

14. Gundersen P. (ed.). 2014. Forest soil carbon sink in the Nordic region. Department of Geosciences and Natural Resource Management, University of Copenhagen, p. 6-8.
15. Hoffmann U., Yair A., Hikel H., Kuhn N. J. 2012. Soil organic carbon in the rocky desert of northern Negev (Israel). Journal of Soil Sediments, 12: 811-825. https://doi.org/10.1007/s11368-012-0499-8

16. Jones D. L., Nguyen C., Finlay R. D. 2009. Carbon flow in the rhizosphere: carbon trading at the soil-root interface. Plant and Soil, 321: 5-33. https://doi.org/10.1007/s11104-009-9925-0

17. Kaiser K., Kalbitz K. 2012. Cycling downwards - dissolved organic matter in soils. Soil Biology and Biochemistry, 52: 29-32. https://doi.org/10.1016/j.soilbio.2012.04.002

18. Kaisermann A., Ogée J., Sauze J., Wohl S., Jones S. P., Gutierrez A., Wingate L. 2018. Disentangling the rates of carbonyl sulfide (COS) production and consumption and their dependency on soil properties across biomass and land use types. Atmospheric Chemistry and Physics, 18: 9425-9440. https://doi.org/10.5194/acp-18-9425-2018

19. Kujur M., Patel A. K. 2012. Quantifying the contribution of different soil properties on microbial biomass carbon, nitrogen and phosphorous in dry tropical ecosystem. International Journal of Environmental Sciences, 2: 2272-2284.

20. Li J., Zhang Q., Li Y., Liu Y., Xu J., Di H. 2017. Effects of long-term mowing on the fractions and chemical composition of soil organic matter in a semiarid grassland. Biogeosciences, 14: 2685-2696.

https://doi.org/10.5194/bg-14-2685-2017

21. Liaudanskienè I. 2009. The influence of sustainable soil tillage and crop rotations on the distribution of carbon in soil fractions: doctoral dissertation. Lithuanian Research Centre for Agriculture and Forestry, $114 \mathrm{p}$.

22. Nikitin B. A. 1999. Methods for soil humus determination. AgroChemistry, 3 (2): 156-158.

23. Plesevičienè A. 1993. Influence of manuring an agrochemical properties in acid and limed soils. Būda V. (ed.). Baltic region: agriculture in acid soils. Lithuania, p. $163-167$.

24. Raudonius S. 2017. Application of statistics in plant and crop research: important issues. Zemdirbyste-Agriculture, 104 (4): 377-382. https://doi.org/10.13080/z-a.2017.104.048

25. Repšienė R., Karčauskienè D. 2016. Changes in the chemical properties of acid soil and aggregate stability in the whole profile under longterm management history. Acta Agriculture Scandinavica, Section B: Soil and Plant Science, 66: 671-676. https://doi.org/10.1080/09064710.2016.1200130

26. Růžek L, Rủžková M, Voříšek K, Kubát J, Friedlova M, Mikanová O. 2009. Chemical and microbiological characterization of Cambisols, Luvisols and Stagnosols. Plant, Soil and Environment, 55: 231-237.

https://doi.org/10.17221/35/2009-PSE

27. Schmidt M. W. I., Torn M. S., Abiven S., Dittmar T., Guggenberger G., Janssens I. A., Kleber M., KögelKnabner I., Lehmann J., Manning D. A. C., Nannipieri P., Rasse D. P., Weiner S., Trumbore S. E. 2011. Persistance of soil organic matter as an ecosystem property. Nature, 478: 49-56. https://doi.org/10.1038/nature10386

28. Schinner F., Ölinger R., Kandeler E., Margesin R. 1993. Bodenbiologische Arbeitsmethoden. Springer-Verlag, 389 p. (in German). https://doi.org/10.1007/978-3-642-77936-7

29. Schulz E., Deller B., Hoffmann G. 2004. C und N im Heißwasserextract. Method A 4.3.2. Das VDLUFA Methodenbuch I, 24 p. (in German).

30. Shi A., Marschner P. 2014. Changes in microbial biomass $\mathrm{C}$, extractable $\mathrm{C}$ and available $\mathrm{N}$ during the early stages of decomposition of residue mixtures. Soil Research, 52: 336-372. https://doi.org/10.1071/SR13128 
31. Skuodienė R., Tomchuk D., Aleinikovienè J. 2017. Plant root morphology and soil biological indicators under primary development of various swards. Acta Agriculture Scandinavica, Section B: Soil and Plant Science, 67: 435-443.

https://doi.org/10.1080/09064710.2017.1293724

32. Tomchuk D. 2018. Grassland belowground biomass and organic carbon accumulation in different terrain ecosystems: doctoral dissertation. Lithuanian Research Centre for Agriculture and Forestry, $132 \mathrm{p}$.

33. Vance E. D., Brookes P. C., Jenkinson D. S. 1987. An extraction method for measuring soil microbial biomass C. Soil Biology and Biochemistry, 19: 703-707. https://doi.org/10.1016/0038-0717(87)90052-6
34. WRB. 2014. World reference base for soil resources. World Soil Resources Reports No. 106. FAO, p. 187-189.

35. Zechmeister-Boltenstern S., KeiblingerK. M., Mooshammer M., Peñuelas J., Richter A., Sardans J., Wanek W. 2015. The application of ecological stoichiometry to plantmicrobial-soil organic matter transformations. Ecological Monographs, 85: 133-155.

https://doi.org/10.1890/14-0777.1

ISSN 1392-3196 / e-ISSN 2335-8947

Zemdirbyste-Agriculture, vol. 107, No. 1 (2020), p. 3-10

DOI 10.13080/z-a.2020.107.001

\title{
Dirvožemio kvėpavimo intensyvumas ir mikroorganizmų biomasès ypatumai taikant skirtingo intensyvumo žemėnaudą
}

\author{
${ }^{1}$ Lietuvos agrarinių ir miškų mokslų centro Miškų institutas \\ ${ }^{2}$ Vytauto Didžiojo universiteto Žemès ūkio akademija \\ ${ }^{3}$ Lietuvos agrarinių ir miškų mokslų centro Véžaičių filialas
}

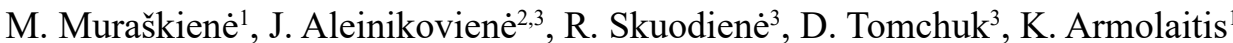

\section{Santrauka}

Agroekosistemose svarbu palaikyti dirvožemio agroekologinị potencialą ir produktyvumo didèjimą, kurie priklauso nuo dirvožemio organinès anglies kiekio, biologinio aktyvumo ir mikroorganizmų biomasès, užtikrinančiu jo ekologines funkcijas. Tyrimo tikslas - ịvertinti dirvožemio mikroorganizmų kvėpavimo intensyvumą ir biomasės kieki nepasotintajame balkšvažemyje taikant skirtingo intensyvumo žemėnauda. Sie rodikliai buvo tirti mineralinio dirvožemio $0-10$ ir 10-20 cm sluoksniuose skirtingo naudojimo intensyvumo žemėnaudose: 1) ariama žemė (>70 metų javų sejjomaina), 2) trumpalaikis žolynas (>70 metų javų sëjomaina su laikinomis pievomis), 3) daugiametis žolynas (agrarinès kilmès 15-20 metų pusiau natūralios pievos) ir 4) karpotojo beržo medynas (25 metų natūralus medynas agrarinès kilmès dirvožemyje).

Atlikus tyrimą, intensyviausias dirvožemio mikroorganizmų kvėpavimas buvo nustatytas daugiamečiame žolyne, beržyne ir trumpalaikiame žolyne vidutinio rūgštumo $(\mathrm{pH} 5,0)$ dirvožemyje. Dirvožemio mikroorganizmų biomasės anglies ir azoto koncentracijos buvo didžiausios beržyne, mažiausios - ariamoje žemèje. Mikroorganizmų aktyvumui (kvèpavimui ir biomasès anglies bei azoto kiekiui) daugeliu atveju turi ịtakos dirvožemio organinès anglies, vandenyje tirpios organinès anglies, humuso kiekiai, jo frakcinè sudètis ir dirvožemio rūgštumas, tačiau šio tyrimo metu tarp minètu savybiu stipriu koreliaciniu ryšiu nebuvo nustatyta. Visgi ilgalaikejje dirvožemio naudojimo perspektyvoje ariamų žemių keitimas daugiametėmis pievomis arba miško želdiniais gali stabilizuoti dirvožemio mikroorganizmų veiklą dèl pastovaus organinių medžiagų kiekio.

Reikšminiai žodžiai: dirvožemio kvėpavimo intensyvumas, dirvožemio organinè anglis, ilgalaikès žemėnaudos skirtingi biotopai, mikroorganizmų biomasès anglis, mikroorganizmų biomasès azotas. 